\title{
High concentrations of mast cell chymase facilitate the transduction of the transforming growth factor-\$1/Smads signaling pathway in skin fibroblasts
}

\author{
XIANGLIN DONG ${ }^{1}$, CHUANSHAN ZHANG $^{2}$, SHAOLIN MA $^{1}$ and HAO WEN ${ }^{2}$ \\ ${ }^{1}$ Department of Burns and Plastic Surgery; ${ }^{2}$ State Key Laboratory Incubation Base of Xinjiang Major Diseases Research, \\ Clinical Medical Research Institute, The First Affiliated Hospital of Xinjiang Medical University, \\ Ürümqi, Xinjiang 830011, P.R. China
}

Received May 6, 2014; Accepted December 22, 2014

DOI: $10.3892 /$ etm.2015.2216

\begin{abstract}
The aim of the present study was to investigate the effect of different concentrations of mast cell chymase on the transforming growth factor (TGF)- $\beta 1 /$ Smad signaling pathway in skin fibroblasts. Cultured skin fibroblasts were treated with various concentrations of chymase for different time periods. A 3-(4,5-dimethylthiazol-2-yl)-2,5-diphenyltetrazolium bromide assay was used to assess the rate of cell proliferation. In addition, protein expression in the fibroblasts was measured using western blot analysis. Chymase was shown to enhance the proliferation of skin fibroblasts following incubation for 48 , 72 and $96 \mathrm{~h}(\mathrm{P}<0.01)$. Furthermore, high concentrations of mast cell chymase were shown to enhance the mRNA and protein expression levels of TGF- $\beta 1$ after long-term $(\geq 6 \mathrm{~h})$ incubation. In addition, high concentrations of mast cell chymase increased P-Smad2/3 and Smad2/3 protein expression. By contrast, low concentrations of mast cell chymase increased Smad7 protein expression. Therefore, the results demonstrated that high concentrations of mast cell chymase facilitated the transduction of the TGF- $\beta 1 /$ Smad signaling pathway in skin fibroblasts.
\end{abstract}

Correspondence to: Dr Hao Wen, State Key Laboratory Incubation Base of Xinjiang Major Diseases Research, Clinical Medical Research Institute, The First Affiliated Hospital of Xinjiang Medical University, 137 Liyushan South Road, Ürümqi, Xinjiang 830011, P.R. China

E-mail: dongxianglin8@21cn.com

Dr Shaolin Ma, Department of Burns and Plastic Surgery, The First Affiliated Hospital of Xinjiang Medical University, 137 Liyushannan Road, Ürümqi, Xinjiang 830011, P.R. China

E-mail: mashaolin9@163.com

Key words: mast cell chymase, fibroblast, transforming growth factor- $\beta 1$, Smads

\section{Introduction}

Skin wound healing is one of the most complex biological processes and is affected by multiple factors. The process involves three steps of inflammation, cell proliferation and tissue remodeling, in order to maintain the body homeostasis (1). This complex process is regulated by a signaling network system with the same complexity, which includes numerous growth factors, cytokines and chemokines $(2,3)$. Following activation, transforming growth factor (TGF)- $\beta$, a key regulator in wound healing, can stimulate extracellular matrix deposition and angiogenesis by regulating the proliferation of fibroblasts $(2,4)$. The action of TGF- $\beta$ is accomplished through the Smad signaling pathways (5).

Autophosphorylation of TGF- $\beta$ occurs after binding to the heterodimer receptor complex, which activates the downstream transcription factor signaling molecules that belong to the Smad protein family $(2,3)$. Following activation, TGF- $\beta$ receptors induce the phosphorylation of Smad2 and Smad3, forming hetero-oligomeric complexes with Smad4 (6-8). The complexes are transported into the nucleus where they regulate ligand-induced gene transcription. The signaling pathway following the activation of the TGF- $\beta$ receptor is further regulated by Smad7, which functions as an intracellular antagonist (9). Smad7 can firmly bind to the activated TGF- $\beta 1$ receptor, inhibit the phosphorylation of R-Smad and hence inhibit the signaling pathway (9).

Mast cell chymase is a type of serine proteinase that is included in the secretory granules of mast cells. Following activation, mast cell chymase can transform inactivated TGF- $\beta 1$ into an activated form $(10,11)$. Taipale et al (12) demonstrated that in the extracellular matrix of human epithelial and endothelial cells, chymase facilitates the release of TGF- $\beta 1$ from the bound protein. Mast cell chymase can increase the concentration of TGF- $\beta 1$ in cultured fibroblasts; however, the increase in TGF- $\beta 1$ can be attenuated using a chymase inhibitor (13). In addition, a neutralizing antibody of TGF- $\beta 1$ has been shown to completely inhibit chymase-induced fibroblast proliferation, indicating that chymase promotes cell proliferation through TGF- $\beta 1$ (13). Furthermore, chymase regulates the formation of angiotensin II (Ang II) (14), degrades procollagen in 
tissue remodeling $(15,16)$ and participates in inflammatory responses $(17,18)$.

Mast cells originate from bone marrow $\mathrm{CD} 34^{+}$hematopoietic stem cells, and are distributed to various tissues via the blood circulation. Mature mast cells are only found in tissues, and those found in the blood are precursors. Previous studies have revealed that chymase promotes the proliferation of skin fibroblasts in a dose- and time-dependent manner (19), and chymase may be involved in the wound healing process $(20,21)$. Chymase is known to activate TGF- $\beta 1(10,11)$, which plays a central role in wound healing and fibrosis (22). In addition, chymase has been reported to induce myocardial fibrosis via the activation of the TGF- $\beta 1 /$ Smad signaling pathway (23). However, the effect of chymase on the TGF- $\beta 1 /$ Smad signaling pathway in skin fibroblasts remains unknown. In the present study, the effects of different concentrations of mast cell chymase were investigated on the TGF- $\beta 1 /$ Smad signaling pathway in skin fibroblasts.

\section{Materials and methods}

Cell culture. Skin tissues were obtained from patients treated at the Department of Burns and Plastic Surgery in the First Affiliated Hospital of Xinjiang Medical University (Ürümqi, China). The collection and use of tissue samples were approved by the Ethics Committee of the First Affiliated Hospital of Xinjiang Medical University. Written informed consent was obtained from all the participants.

Skin tissues were cut in sterile conditions and placed into phosphate-buffered saline containing 100,000 U/1 penicillin and $100 \mathrm{mg} / \mathrm{l}$ streptomycin. After soaking for $30 \mathrm{~min}$, the tissues were transferred to Petri dishes where the subcutaneous tissues were eliminated, and the samples were cut into small strips. The tissues were digested with $0.25 \%$ Dispase II (Sigma-Aldrich, St. Louis, MO, USA) at $4^{\circ} \mathrm{C}$ overnight. After removing the epidermis, the isolated dermis was cut into sections of $1-2 \mathrm{~mm}^{3}$. The tissue sections were digested at $37^{\circ} \mathrm{C}$ with shaking for $3 \mathrm{~h}$. The filtrate was collected via a $150 \mu \mathrm{m}$ mesh (Tiantai Global Screen Mesh Co., Ltd., Taizhou, China), and the remainder was centrifuged at $1,000 \mathrm{xg}$ for $10 \mathrm{~min}$ to collect the cells. The cells were seeded onto Petri dishes at a density of $2 \times 10^{4}$ cells $/ \mathrm{cm}^{2}$ and cultured at $37^{\circ} \mathrm{C}$ in the presence of $5 \% \mathrm{CO}_{2}$. The medium was changed after $4 \mathrm{~h}$ incubation, following which the medium was changed every three days. Cell growth and shapes were observed under an inverted microscope (BX50; Olympus, Tokyo, Japan). The third to sixth generations of the cells were used for further study.

3-(4,5-dimethylthiazol-2-yl)-2,5-diphenyltetrazolium bromide (MTT) assay. Cell proliferation was analyzed using an MTT assay. Cultured fibroblasts were trypsinized, made into a single cell suspension ( $1 \times 10^{6}$ cells $\left./ \mathrm{ml}\right)$ and seeded onto $96-$ well plates for incubation for $24 \mathrm{~h}$. The cells were divided into five groups for the addition of different concentrations $(0,15,30$, 60 and $120 \mathrm{ng} / \mathrm{ml}$ ) of chymase (C8118; Sigma-Aldrich). The five groups of cells were cultured for 24, 48, 72 and $96 \mathrm{~h}$, followed by the addition of $20 \mu \mathrm{l}$ MTT $(0.5 \%)$ per well prior to continued culture for an additional $4 \mathrm{~h}$. The supernatants were discarded, and $100 \mu \mathrm{l}$ dimethyl sulfoxide was added to each well prior to shaking for $10 \mathrm{~min}$. Optical density $(490 \mathrm{~nm})$ values were measured using a microplate reader (Thermo Plate TP-Reader; Thermo Fisher Scientific, Waltham, MA, USA). All the experiments were performed in triplicate.

Quantitative polymerase chain reaction ( $q P C R)$. Skin fibroblasts were cultured in the presence of different concentrations $(0,15,30,60$ and $120 \mathrm{ng} / \mathrm{ml})$ of chymase for 6,12 and $24 \mathrm{~h}$. Following cell culture, the total RNA was isolated using TRIzol reagent (Invitrogen Life Technologies, Carlsbad, CA, USA). qPCR was conducted using SYBR Premix Ex Taq ${ }^{\mathrm{TM}}$ (Takara Bio, Inc., Otsu, Japan) on an IQ5 qRT-PCR system (Bio-Rad Laboratories, Hercules, CA, USA). PCR amplification conditions were as follows: Initial denaturation at $95^{\circ} \mathrm{C}$ for $30 \mathrm{sec}$, followed by 40 cycles of amplification at $95^{\circ} \mathrm{C}$ for $5 \mathrm{sec}$, $55^{\circ} \mathrm{C}$ for $30 \mathrm{sec}$ and $72^{\circ} \mathrm{C}$ for $60 \mathrm{sec}$. The temperature range for the dissolution curve was $65-95^{\circ} \mathrm{C}$. The $2^{-\Delta \Delta \mathrm{Ct}}$ method was used to calculate the gene expression levels of TGF- $\beta 1$ relative to glyceraldehyde-3-phosphate dehydrogenase (GAPDH). The sequences of the specific primers were as follows: TGF- $\beta 1$ (158 bp), 5'-ACACCAACTATTGCTTCAG-3' (sense) and 5'-TGTCCAGGCTCCAAATG-3' (antisense); GAPDH (137 bp), 5'-GCACCGTCAAGGCTGAGAAC-3' (sense) and 5'-TGGTGAAGACGCCAGTGGA-3' (antisense). Each PCR trial was performed with three samples and repeated a minimum of three times.

Bicinchoninic acid (BCA) assay. Cells were seeded into six-well plates at a density of $5 \times 10^{4}$ cells/well. The cells were incubated with various concentrations of chymase for 6,12 and $24 \mathrm{~h}$. Following incubation, the cells were washed with ice-cold phosphate-buffered saline, and lysed in $500 \mu \mathrm{l}$ ice-cold radioimmunoprecipitation assay buffer (BioTeke Corporation, Beijing, China), containing $1 \mu \mathrm{g} / \mathrm{ml}$ phosphatase inhibitors and $1 \mathrm{mM}$ phenylmethanesulfonyl fluoride, for $30 \mathrm{~min}$. The mixture was centrifuged at $12,000 \times \mathrm{g}\left(4^{\circ} \mathrm{C}\right)$ for $10 \mathrm{~min}$, after which the supernatants were stored at $-80^{\circ} \mathrm{C}$. The concentration of TGF- $\beta 1$, phosphorylated Smad2/3 (P-Smad2/3), Smad2/3, Smad7 and GAPDH proteins were measured using a BCA protein assay kit (BioTeke Corporation).

Western blot analysis. A prestained marker with a low molecular weight and $30 \mu \mathrm{g}$ protein from the tissue samples were subject to sodium dodecyl sulfate polyacrylamide gel electrophoresis. The separated proteins were transferred onto polyvinylidene fluoride membranes (EMD Millipore, Billerica, MA, USA) and blocked in Tris-buffered saline and Tween-20 [10 mM Tris (pH 7.6), $150 \mathrm{mM} \mathrm{NaCl}$ and $0.1 \%$ Tween-20] containing 5\% skimmed milk for $1 \mathrm{~h}$ at room temperature. Subsequently, the membranes were incubated with primary antibodies against TGF- $\beta 1$ (sc-146; 1:300; Santa Cruz Biotechnology, Inc., Santa Cruz, CA, USA), P-Smad2/3 (8828s; 1:1,000; Cell Signaling Technology, Inc., Beverly, MA, USA), Smad2/3 (sc-8332; 1:300; Santa Cruz Biotechnology, Inc.), Smad7 (sc-11392; 1:300; Santa Cruz Biotechnology, Inc.) and GAPDH (sc-25778; 1:300; Santa Cruz Biotechnology, Inc.) at $4^{\circ} \mathrm{C}$ overnight. The blots were rinsed in Tris-buffered saline and Tween-20, and incubated with an alkaline phosphatase-conjugated secondary antibody (77054s; 1:1,000; Cell Signaling Technology, Inc.) for $2 \mathrm{~h}$ at room temperature. Bands on the western blots 


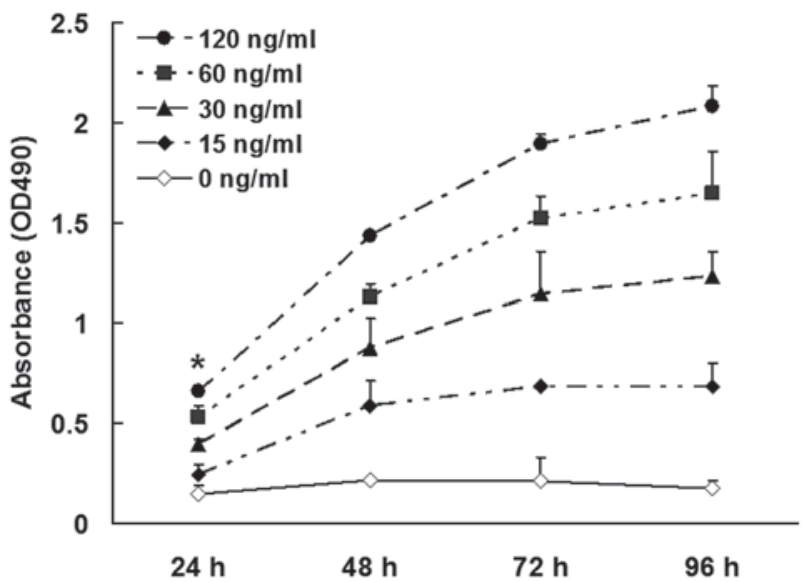

Figure 1. Proliferation of the skin fibroblasts was analyzed using an 3-(4,5-dimethylthiazol-2-yl)-2,5-diphenyltetrazolium bromide (MTT) assay. Cultured fibroblasts were trypsinized, made into a single cell suspension $\left(1 \times 10^{6}\right.$ cells $\left./ \mathrm{ml}\right)$ and seeded onto 96 -well plates for incubation for $24 \mathrm{~h}$. The cells were divided into five groups for the addition of different concentrations $(0,15,30,60$ and $120 \mathrm{ng} / \mathrm{ml})$ of chymase and cultured for $24,48,72$ and $96 \mathrm{~h}$, followed by the addition of $20 \mu \mathrm{l}$ MTT $(0.5 \%)$ per well and continued culture for an additional $4 \mathrm{~h}$. OD $(490 \mathrm{~nm})$ values were measured and the experiments were performed in triplicate. Data are expressed as the mean \pm standard deviation. ${ }^{*} \mathrm{P}<0.01$, vs. other groups. OD, optical density.

were visualized using a 5-bromo-4-chloro-3-indolyl phosphate/nitroblue tetrazolium kit (Invitrogen Life Technologies), according to the manufacturer's instructions. Optical densities of the bands were scanned and quantified using Quantity One image analysis software (Bio-Rad Laboratories).

Statistical analysis. All statistical analyses were performed using SPSS 17.0 software for Windows (SPSS, Inc., Chicago, IL, USA). Data are presented as the mean \pm standard deviation. Statistical differences between groups were assessed by one-way analysis of variance, followed by the least significant difference post hoc test. $\mathrm{P}<0.05$ was considered to indicate a statistically significant difference.

\section{Results}

Mast cell chymase increases skin fibroblast proliferation in a dose-and time-dependent manner. To analyze the effect of different concentrations of mast cell chymase on the proliferation of skin fibroblasts following incubation for 24, 48, 72 and $96 \mathrm{~h}$, an MTT assay was performed. The results revealed that chymase $(15,30,60$ and $120 \mathrm{ng} / \mathrm{ml})$ enhanced the proliferation of skin fibroblasts following incubation for 48, 72 and $96 \mathrm{~h}$ $(\mathrm{P}<0.01)$. As the incubation time increased, the proliferation was enhanced (Fig. 1). These results indicated that mast cell chymase increased skin fibroblast proliferation in a dose- and time-dependent manner.

High concentrations of mast cell chymase enhance the mRNA and protein expression levels of TGF- $\beta 1$ after long-term incubation. To analyze the effect of various concentrations of mast cell chymase on the mRNA and protein expression levels of TGF- $\beta 1$ after incubation for 6,12 and $24 \mathrm{~h}, \mathrm{qPCR}$ and western blot analysis were employed, respectively. The qPCR results revealed that the mRNA expression levels of TGF- $\beta 1$ following incubation with chymase at concentrations of 60 and $120 \mathrm{ng} / \mathrm{ml}$ for 6,12 and $24 \mathrm{~h}$ were significantly higher compared with those incubated with chymase at concentrations of 0,15 and $30 \mathrm{ng} / \mathrm{ml}(\mathrm{P}<0.01$; Fig. $2 \mathrm{~A})$. In addition, western blot analysis demonstrated that TGF- $\beta 1$ protein expression following incubation with chymase at 60 and $120 \mathrm{ng} / \mathrm{ml}$ for 6,12 and $24 \mathrm{~h}$ was significantly higher compared with that in the control group ( $0 \mathrm{ng} / \mathrm{ml}$; $\mathrm{P}<0.01)$. However, TGF- $\beta 1$ protein expression levels following incubation with 15 and $30 \mathrm{ng} / \mathrm{ml}$ chymase were slightly lower compared with that in the control group (0 ng/ml; Fig. 2B). These results indicated that high concentrations of mast cell chymase $(60$ and $120 \mathrm{ng} / \mathrm{ml})$ enhanced the mRNA and protein expression levels of TGF- $\beta 1$ following incubation for $\geq 6 \mathrm{~h}$.

High concentrations of mast cell chymase increase $P-S m a d 2 / 3$ and Smad2/3 protein expression, whereas low concentrations of mast cell chymase increase Smad7 protein expression. To measure the protein expression levels of P-Smad2/3, Smad2/3 and Smad7, western blot analysis was performed. The assay revealed that the protein expression levels of P-Smad2/3 and Smad2/3 following incubation with chymase (60 and $120 \mathrm{ng} / \mathrm{ml}$ ) for 6,12 and $24 \mathrm{~h}$ were significantly higher compared with those in the control group (0 ng/ml; P<0.05). However, P-Smad2/3 and Smad2/3 protein expression levels following incubation with chymase at a concentration of 15 and $30 \mathrm{ng} / \mathrm{ml}$ were slightly lower compared with those in the control group $(0 \mathrm{ng} / \mathrm{ml}$; Figs. 3A, $\mathrm{B}$ and 4). By contrast, protein expression levels of Smad7 following incubation with 60 and $120 \mathrm{ng} / \mathrm{ml}$ chymase for $6 \mathrm{~h}$ were slightly lower compared with those in the control group $(0 \mathrm{ng} / \mathrm{ml})$, whereas $\mathrm{Smad} 7$ protein expression levels following incubation with 15 and $30 \mathrm{ng} / \mathrm{ml}$ chymase for $6 \mathrm{~h}$ were significantly higher compared with those in the control group $(0 \mathrm{ng} / \mathrm{ml})(\mathrm{P}<0.05$; Figs. $3 \mathrm{C}$ and 4$)$. In addition, the protein expression levels of Smad7 following incubation with chymase $(15,30,60$ and $120 \mathrm{ng} / \mathrm{ml})$ for 12 and $24 \mathrm{~h}$ were all higher compared with those in the control group (0 ng/ml). A statistically significant difference was observed in the Smad7 protein expression levels between those incubated with 15 and $30 \mathrm{ng} / \mathrm{ml}$ chymase and those incubated with chymase at 60 and $120 \mathrm{ng} / \mathrm{ml}(\mathrm{P}<0.05$; Figs. 3C and 4). These results indicated that high concentrations of mast cell chymase $(60$ and $120 \mathrm{ng} / \mathrm{ml}$ ) increased $\mathrm{P}-\mathrm{Smad} 2 / 3$ and $\mathrm{Smad} 2 / 3$ protein expression, whereas low concentrations of mast cell chymase (15 and $30 \mathrm{ng} / \mathrm{ml}$ ) increased $\mathrm{Smad} 7$ protein expression.

\section{Discussion}

One of the most important functions of mast cell chymase is the regulation of Ang II formation (14). Ang II directly acts on vascular smooth muscle to regulate the blood pressure and is associated with tissue fibrosis. In addition, chymase promotes the proliferation of fibroblasts in heart muscle and skin tissues (23-25), and promotes the release of TGF- $\beta 1$ bound to the extracellular matrix (26). Furthermore, chymase is known to degrade procollagen for tissue remodeling $(15,16)$ and participate in the inflammatory response $(17,18)$.

A previous study demonstrated that chymase can activate the potential of TGF- $\beta 1$. In cultured fibroblasts, chymase promotes 
A

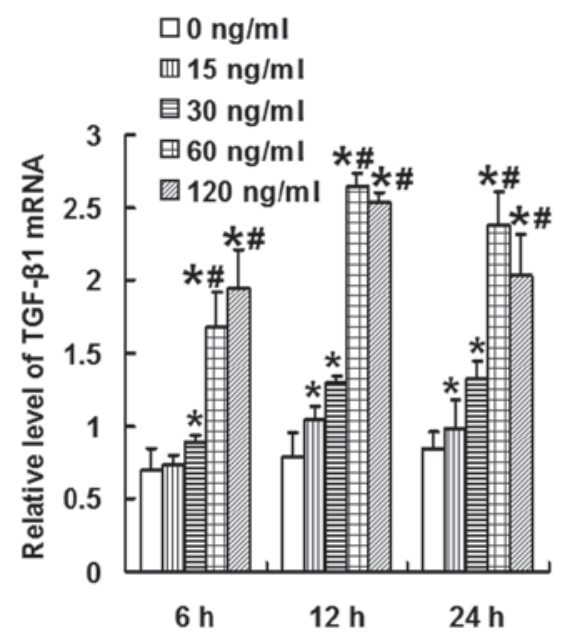

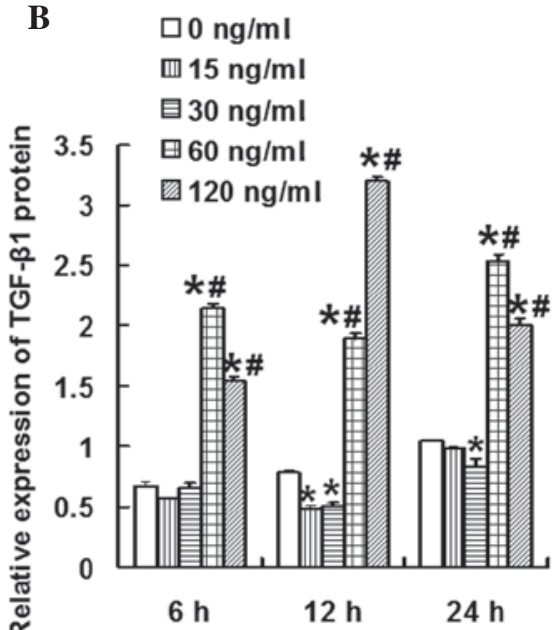

Figure 2. (A) mRNA and (B) protein expression levels of TGF- $\beta 1$ in skin fibroblasts treated with chymase $(0,15,30,60 \mathrm{and} 120 \mathrm{ng} / \mathrm{ml})$ for 6,12 and $24 \mathrm{~h}$, as determined using quantitative polymerase chain reaction and western blot analysis, respectively. Data are expressed as the mean \pm standard deviation. "P<0.05, vs. the $0 \mathrm{ng} / \mathrm{ml}$ concentration group; ${ }^{\#} \mathrm{P}<0.05$, vs. the 15 and $30 \mathrm{ng} / \mathrm{ml}$ groups. TGF, transforming growth factor.

A

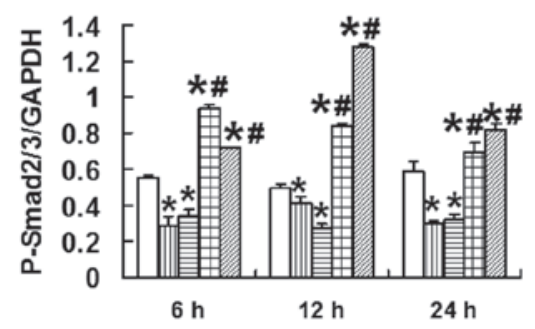

C

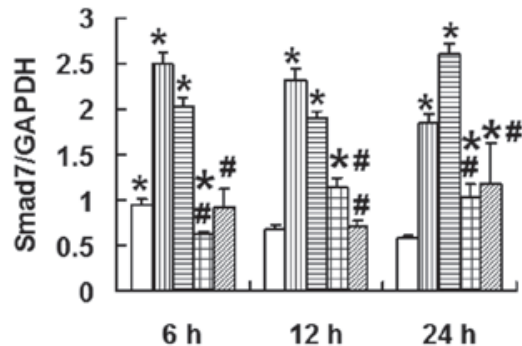

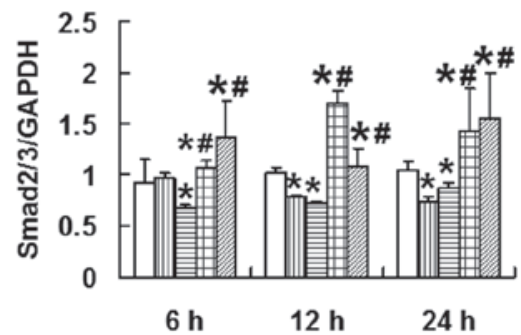

$\square 0 \mathrm{ng} / \mathrm{ml}$

四15 $\mathrm{ng} / \mathrm{ml}$

目 $30 \mathrm{ng} / \mathrm{ml}$

巴 $60 \mathrm{ng} / \mathrm{ml}$

圆 $120 \mathrm{ng} / \mathrm{ml}$

Figure 3. Protein expression of (A) P-Smad2/3, (B) Smad2/3 and (C) Smad7 in skin fibroblasts treated with chymase (0, 15, 30, 60 and $120 \mathrm{ng} / \mathrm{ml})$ for 6, 12 and $24 \mathrm{~h}$. Data are expressed as the mean \pm standard deviation. ${ }^{*} \mathrm{P}<0.05$, vs. the $0 \mathrm{ng} / \mathrm{ml}$ concentration group; ${ }^{*} \mathrm{P}<0.05$, vs. the $15 \mathrm{and} 30 \mathrm{ng} / \mathrm{ml}$ groups. $\mathrm{P}-\mathrm{Smad} 2 / 3$, phosphorylated Smad2/3.

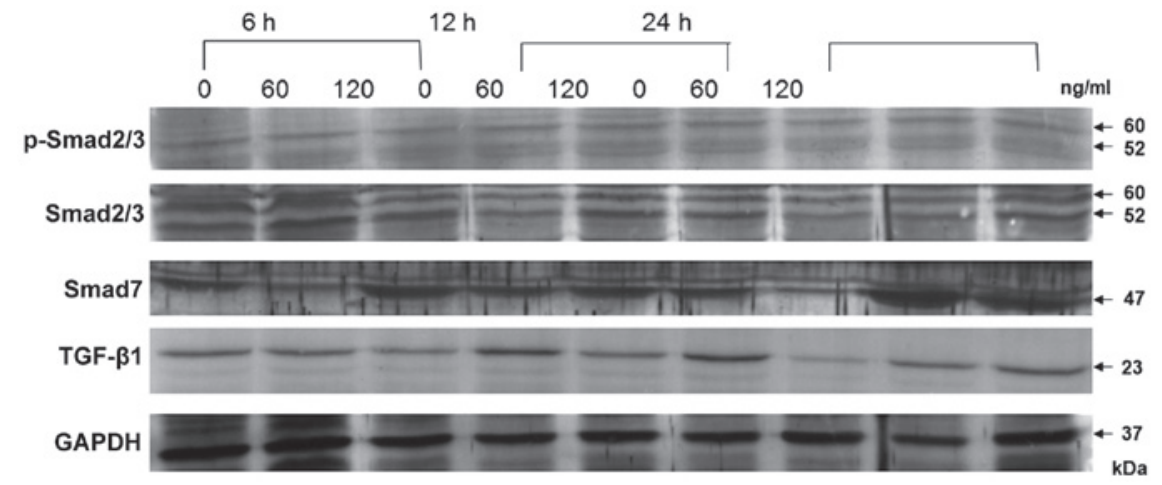

Figure 4. Western blots analysis showing the protein expression of P-Smad2/3, Smad2/3, Smad7, TGF- $\beta 1$ and GAPDH in skin fibroblasts treated with chymase $(0,60$ and $120 \mathrm{ng} / \mathrm{ml})$ for 6, 12 and $24 \mathrm{~h}$. TGF, transforming growth factor; GAPDH, glyceraldehyde-3-phosphate dehydrogenase; P-Smad2/3, phosphorylated $\operatorname{Smad} 2 / 3$. 
the release of TGF- $\beta 1$ from the bound protein (27). In human skin fibroblasts, chymase significantly increases the proliferation of fibroblasts; however, this process can be completely inhibited by chymase inhibitors, rather than Ang II receptor blockers (26). Chymase can facilitate the protein expression of TGF- $\beta 1$ in fibroblasts; however, increased TGF- $\beta 1$ levels can be inhibited by the chymase inhibitor, Suc-Val-Pro-Phep $(\mathrm{OPh})_{2}$. Furthermore, an anti-TGF- $\beta 1$ neutralizing antibody has been shown to completely inhibit chymase-induced cell proliferation, which may be mediated by the activation of TGF- $\beta 1$ (28).

TGF- $\beta$ is a secretory polypeptide signaling molecule that participates in a variety of pathophysiological processes in mammals. TGF- $\beta$ affects cell proliferation and differentiation, and plays an important role in embryo development, extracellular matrix formation and immunoregulation. The subtype, TGF- $\beta 1$, is closely associated with extracellular matrix deposition and fibrotic diseases, and is one of the main factors that affects wound healing and scar formation (29). In the present study, different concentrations of chymase were shown to affect the proliferation of skin fibroblasts in a dose- and time-dependent manner, which was consistent with the results of a previous study (19).

TGF- $\beta 1$ mRNA expression levels in the skin fibroblasts following treatment with mast cell chymase $(15$ and $30 \mathrm{ng} / \mathrm{ml})$ were higher compared with those in the control group; however, the protein expression levels following treatment with chymase at a concentration of 15 and $30 \mathrm{ng} / \mathrm{ml}$ were lower compared with those in the control group. In addition, TGF- $\beta 1$ mRNA and protein expression levels following treatment with mast cell chymase at concentrations of 60 and $120 \mathrm{ng} / \mathrm{ml}$ were significantly higher compared with those following treatment with mast cell chymase at a concentration of 15 and $30 \mathrm{ng} / \mathrm{ml}$.

Smads are signaling intermediates and antagonists of the TGF- $\beta$ superfamily that are responsible for the intracellular signaling and regulation of TGF- $\beta 1$ (7). The initial process of Smad pathway activation is R-Smad phosphorylation. Smad7 prevents the activation of R-Smad and downregulates TGF- $\beta 1$ signaling. The TGF- $\beta 1 /$ Smad signaling pathway plays an important role in skin development and wound healing (30-32). Chymase has been reported to induce myocardial fibrosis via the TGF- $\beta 1 /$ Smad signaling pathway in cultured mouse cardiac fibroblasts (23). However, the effect of chymase on the TGF- $\beta 1 /$ Smad signaling pathway in cultured human skin fibroblasts has not been reported previously.

In the present study, Smad2/3 and P-Smad2/3 protein expression levels in the fibroblasts treated with mast cell chymase (60 and $120 \mathrm{ng} / \mathrm{ml}$ ) for 6,12 and $24 \mathrm{~h}$ were higher compared with those in the control group. However, in the fibroblasts treated with 15 and $30 \mathrm{ng} / \mathrm{ml}$ chymase, the protein expression levels were lower compared with the control group. By contrast, Smad7 protein expression levels in the skin fibroblasts treated with 15 and $30 \mathrm{ng} / \mathrm{ml}$ chymase were higher compared with the control group and the 60 and $120 \mathrm{ng} / \mathrm{ml}$ chymase groups. The higher the TGF- $\beta 1$ protein expression levels, the lower the Smad7 protein expression levels, and vice versa.

Phosphorylation of Smad2/3 is a key step in the activation of the Smad signaling pathway (33). The amount of $\mathrm{P}-\mathrm{Smad} 2 / 3$ protein represents the degree of activation of the Smad signaling pathway. The aforementioned results demonstrated that chymase can activate the Smad signaling pathway. However, Smad proteins are not the only proteins activated by TGF- $\beta(34,35)$, and may be associated with other signaling pathways. Thus, whether chymase is able to activate other signaling pathways requires further investigation.

Smad7 is the primary inhibitory protein in the TGF- $\beta 1$ signaling pathway. The protein competitively binds to activated TGF- $\beta$ receptor 1 to prevent the phosphorylation of $\mathrm{R}-\mathrm{Smad}$; thus, causing the downregulation of the Smad signaling pathway (36). In the present study, chymase at concentrations of 15 and $30 \mathrm{ng} / \mathrm{ml}$ significantly enhanced Smad7 protein expression, which was consistent with a previous study that reported TGF- $\beta 1$ induced Smad7 protein expression in skin fibroblasts (37). Chymase can activate $\mathrm{Smad} 2 / 3$, and can increase Smad7 expression, forming an autocrine negative feedback loop. However, the expression of endogenous Smad7 induced by 60 and $120 \mathrm{ng} / \mathrm{ml}$ chymase was much lower compared with the protein expression levels of TGF- $\beta 1, \mathrm{Smad} 2 / 3$ and $\mathrm{P}-\mathrm{Smad} 2 / 3$, which promoted the Smad signaling pathway. The evidence that chymase (60 and $120 \mathrm{ng} / \mathrm{ml}$ ) upregulated the mRNA and protein expression levels of TGF- $\beta 1$ and promoted the phosphorylation of Smad $2 / 3$ protein indicated that chymase activated TGF- $\beta 1$ and the intracellular signaling transduction Smad protein molecules, which promoted the transduction of the TGF- $\beta 1 /$ Smad signaling pathway.

In conclusion, the present study investigated the effects of various concentrations of mast cell chymase on the TGF- $\beta 1 /$ Smad signaling pathway in cultured skin fibroblasts. The results demonstrated that high concentrations of chymase facilitate the transduction of the TGF- $\beta 1 / \mathrm{Smad}$ signaling pathway.

\section{Acknowledgements}

The study was supported by a grant from the Youth Science Foundation of the First Affiliated Hospital of Xinjiang Medical University (no. 2012QN02).

\section{References}

1. Li J, Chen J and Kirsner R: Pathophysiology of acute wound healing. Clin Dermatol 25: 9-18, 2007.

2. Werner S and Grose R: Regulation of wound healing by growth factors and cytokines. Physiol Rev 83: 835-870, 2003.

3. Barrientos S, Stojadinovic O, Golinko MS, Brem H and Tomic-Canic M: Growth factors and cytokines in wound healing. Wound Repair Regen 16: 585-601, 2008.

4. Li J, Zhang YP and Kirsner RS: Angiogenesis in wound repair: angiogenic growth factors and the extracellular matrix. Microsc Res Tech 60: 107-114, 2003.

5. Itoh S, Itoh F, Goumans MJ and Ten Dijke P: Signaling of transforming growth factor-beta family members through Smad proteins. Eur J Biochem 267: 6954-6967, 2000.

6. Ashcroft GS and Roberts AB: Loss of Smad3 modulates wound healing. Cytokine Growth Factor Rev 11: 125-131, 2000.

7. Derynck R, Zhang Y and Feng XH: Smads: transcriptional activators of TGF-beta responses. Cell 95: 737-740, 1998.

8. Massagué J: TGF-beta signal transduction. Annu Rev Biochem 67: 753-791, 1998.

9. Hayashi H, Abdollah S, Qiu Y, et al: The MAD-related protein Smad7 associates with the TGFbeta receptor and functions as an antagonist of TGFbeta signaling. Cell 89: 1165-1173, 1997.

10. Lyons RM, Gentry LE, Purchio AF and Moses HL: Mechanism of activation of latent recombinant transforming growth factor beta 1 by plasmin. J Cell Biol 110: 1361-1367, 1990. 
11. Miyazono K and Heldin $\mathrm{CH}$ : Role for carbohydrate structures in TGF-beta 1 latency. Nature 338: 158-160, 1989.

12. Taipale J, Lohi J, Saarinen J, Kovanen PT and Keski-Oja J: Human mast cell chymase and leukocyte elastase release latent transforming growth factor-beta 1 from the extracellular matrix of cultured human epithelial and endothelial cells. J Biol Chem 270: 4689-4696, 1995.

13. Okamoto Y,TakaiS and MiyazakiM:Effect of chymase-dependent transforming growth factor beta on peritoneal adhesion formation in a rat model. Surg Today 34: 865-867, 2004.

14. Urata H, Kinoshita A, Misono KS, Bumpus FM and Husain A: Identification of a highly specific chymase as the major angiotensin II-forming enzyme in the human heart. J Biol Chem 265 22348-22357, 1990

15. Saarinen J, Kalkkinen N, Welgus HG and Kovanen PT: Activation of human interstitial procollagenase through direct cleavage of the Leu83-Thr84 bond by mast cell chymase. J Biol Chem 269 18134-18140, 1994.

16. Vartio T, Seppä H and Vaheri A: Susceptibility of soluble and matrix fibronectins to degradation by tissue proteinases, mast cell chymase and cathepsin G. J Biol Chem 256: 471-477, 1981.

17. Takai S and Miyazaki M: A novel therapeutic strategy against vascular disorders with chymase inhibitor. Curr Vasc Pharmacol 1: 217-224, 2003.

18. Doggrell SA and Wanstall JC: Vascular chymase: pathophysiological role and therapeutic potential of inhibition. Cardiovasc Res 61: 653-662, 2004.

19. Dong X, Chen J, Zhang Y and Cen Y: Mast cell chymase promotes cell proliferation and expression of certain cytokines in a dose-dependent manner. Mol Med Rep 5: 1487-1490, 2012.

20. Dong X, Geng Z, Zhao Y, Chen J and Cen Y: Involvement of mast cell chymase in burn wound healing in hamsters. Exp Ther Med 5: 643-647, 2013.

21. Nishikori Y, Kakizoe E, Kobayashi Y, et al: Skin mast cell promotion of matrix remodeling in burn wound healing in mice: relevance of chymase. Arch Dermatol Res 290: 553-560, 1998.

22. Massagué J: How cells read TGF-beta signals. Nat Rev Mol Cell Biol 1: 169-178, 2000

23. Zhao XY, Zhao LY, Zheng QS, et al: Chymase induces profibrotic response via transforming growth factor-beta1/Smad activation in rat cardiac fibroblasts. Mol Cell Biochem 310: 159-166, 2008.

24. Maruichi M, Takai S, Sugiyama T, et al: Role of chymase on growth of cultured canine Tenon's capsule fibroblasts and scarring in a canine conjunctival flap model. Exp Eye Res 79: 111-118, 2004.
25. Algermissen B, Hermes B, Feldmann-Boeddeker I, Bauer F and Henz BM: Mast cell chymase and tryptase during tissue turnover: analysis on in vitro mitogenesis of fibroblasts and keratinocytes and alterations in cutaneous scars. Exp Dermatol 8: 193-198, 1999.

26. Takai S, Jin D, Sakaguchi M, et al: A novel chymase inhibitor, 4-[1-([bis-(4-methyl-phenyl)-methyl]-carbamoyl)3(2-ethoxy-benzyl)-4-oxo-azetidine-2-yloxy]-benzoic acid (BCEAB), suppressed cardiac fibrosis in cardiomyopathic hamsters. J Pharmacol Exp Ther 305: 17-23, 2003.

27. Kanzaki T, Olofsson A, Morén A, et al: TGF-beta 1 binding protein: a component of the large latent complex of TGF-beta 1 with multiple repeat sequences. Cell 61: 1051-1061, 1990.

28. Simard E, Jin D, Takai S, et al: Chymase-dependent conversion of Big endothelin-1 in the mouse in vivo. J Pharmacol Exp Ther 328: 540-548, 2009.

29. Rhett JM, Ghatnekar GS, Palatinus JA, O'Quinn M, Yost MJ and Gourdie RG: Novel therapies for scar reduction and regenerative healing of skin wounds. Trends Biotechnol 26: 173-180, 2008.

30. Owens P, Han G, Li AG and Wang XJ: The role of Smads in skin development. J Invest Dermatol 128: 783-790, 2008.

31. Ponugoti B, Xu F, Zhang C, Tian C, Pacios S and Graves DT: FOXO1 promotes wound healing through the up-regulation of TGF- $\beta 1$ and prevention of oxidative stress. J Cell Biol 203: 327-343, 2013.

32. Kajdaniuk D, Marek B, Borgiel-Marek H and Kos-Kudła B: Transforming growth factor $\beta 1$ (TGF $\beta 1$ ) in physiology and pathology. Endokrynol Pol 64: 384-396, 2013.

33. Attisano L and Wrana JL: Signal transduction by the TGF-beta superfamily. Science 296: 1646-1647, 2002.

34. Euler-Taimor $\mathrm{G}$ and Heger J: The complex pattern of SMAD signaling in the cardiovascular system. Cardiovasc Res 69: $15-25,2006$.

35. Rodríguez-Vita J, Sánchez-López E, Esteban V, Rupérez M, Egido J and Ruiz-Ortega M: Angiotensin II activates the Smad pathway in vascular smooth muscle cells by a transforming growth factor-beta-independent mechanism. Circulation 111: 2509-2517, 2005.

36. Nakao A, Afrakhte M, Morén A, et al: Identification of Smad7, a TGFbeta-inducible antagonist of TGF-beta signalling. Nature 389: 631-635, 1997.

37. Mori Y, Chen SJ and Varga J: Modulation of endogenous Smad expression in normal skin fibroblasts by transforming growth factor-beta. Exp Cell Res 258: 374-383, 2000. 